\title{
Detoxication of Timber Milkvetch by 2,4,5-T and Silvex ${ }^{1}$
}

\section{COBURN WILLIAMS}

Plant Physiologist, Crops Research Division, Agricultural Research Service, U.S. Department of Agriculture, Logan, Utah.

\section{Highlight}

Timber milkvetch, Astragalus miser var. oblongifolius, was treated with esters of 2,4,5-T and silvex at $2 \mathrm{lb}$./acre. The concentration of miserotoxin, the poison contained in the plant, decreased rapidly after treatment. After 4 weeks, treated plants contained only one-third as much miserotoxin as the controls.

Poisonous taxonomic varieties of timber milkvetch, Astragalus miser Dougl. ex Hook., cause moderate to

${ }^{1}$ Cooperative investigation of the Crops Research Division, Agricultural Research Service, U.S. Department of Agriculture and the Utah Agricultural Experiment Station, Utah State University, Logan, Utah. Received October 29, 1969; accepted for publication February 13, 1970. severe livestock losses on western ranges from Colorado and Utah to British Columbia. Both cattle and sheep are affected by the plant, but losses among cattle are considerably higher. In British Columbia, cattle losses of 3 to $5 \%$ are common from timber milkvetch (MacDonald, 1952). In some areas 20 to $30 \%$ of the animals may be affected (Nicholson, 1963).

Of eight varieties of timber milkvetch (Barneby, 1964), three are poisonous: oblongifolius (Rydb.) Cronq.; serotinus (Gray) Barneby; and hylophilus (Rydb.) Barneby (Williams and Norris, 1969). Variety oblongifolius occurs on high mountain ranges from Colorado and Utah to southern Wyoming and southeastern Idaho while vari- ety hylophilus grows in Yellowstone and Grand Teton National Parks and adjacent Wyoming, Montana, and Idaho. Variety serotinus is found in British Columbia, the upper Columbia Basin of Washington, and the mountains of western $\mathrm{Al}$ berta.

Poisonous varieties of timber milkvetch contain miserotoxin, the $\beta$ glucoside of 3-nitro-1-propanol $\left(\mathrm{C}_{9} \mathrm{H}_{17} \mathrm{NO}_{8}\right)$ (Stermitz et al., 1969). Miserotoxin is metabolized in the rumen of cattle and sheep to 3nitro-1-propanol (3-NPOH) which is rapidly absorbed and transported to the brain where it affects sites controlling respiratory and muscular responses (Williams et al., 1969); (Williams et al., 1970). Metabolism of miserotoxin also yields inorganic nitrite which combines with hemoglobin to form methemoglobin. Blood methemoglobin concentrations of 25 to $30 \%$ of total hemoglobin are common in affected animals. Methemoglobin analysis, thercforc, can be used as a test for 
Table 1. Miserotoxin content (\%) of timber milkvetch after treatment on June 12, 1969, with esters of silvex and 2,4,5-T at 2 lb./acre.

\begin{tabular}{|c|c|c|c|c|c|c|}
\hline \multirow{2}{*}{$\begin{array}{c}\text { Collec- } \\
\text { tion } \\
\text { date }\end{array}$} & \multicolumn{2}{|c|}{ Control } & \multicolumn{2}{|c|}{ Treated with Silvex } & \multicolumn{2}{|c|}{ Treated with 2,4,5-T } \\
\hline & $\begin{array}{l}\text { Condition } \\
\text { of plant }\end{array}$ & $\begin{array}{l}\text { Misero- } \\
\text { toxin }\end{array}$ & $\begin{array}{l}\text { Condition } \\
\text { of plant }\end{array}$ & $\begin{array}{l}\text { Misero- } \\
\text { toxin }\end{array}$ & $\begin{array}{l}\text { Condition } \\
\text { of plant }\end{array}$ & $\begin{array}{l}\text { Misero- } \\
\text { toxin }\end{array}$ \\
\hline June 12 & Bloom & 2.1 & Bloom & 2.1 & Bloom & 2.1 \\
\hline June 19 & Past bloom & 2.4 & Past bloom & 1.9 & Past bloom & 1.7 \\
\hline July 2 & Early pod & 2.5 & $10 \%$ bleached & 0.9 & $5 \%$ bleached & 1.2 \\
\hline July 9 & Pod & 2.3 & $50 \%$ bleached & 0.6 & $40 \%$ bleached & 0.8 \\
\hline July 17 & Late pod & 2.0 & $90 \%$ bleached & 0.5 & $80 \%$ bleached & 0.7 \\
\hline July 24 & Past seed & 1.9 & $95 \%$ bleached & 0.5 & $90 \%$ bleached & 0.6 \\
\hline July 31 & $25 \%$ bleached & 1.6 & $100 \%$ bleached & 0.3 & $100 \%$ bleached & 0.4 \\
\hline Aug. 7 & $40 \%$ bleached & 1.3 & - & - & - & - \\
\hline Aug. 14 & $80 \%$ bleached & 0.9 & $\longrightarrow$ & - & $\longrightarrow$ & - \\
\hline Aug. 21 & $100 \%$ bleached & 0.4 & $\longrightarrow$ & - & $\longrightarrow$ & 一 \\
\hline
\end{tabular}

timber milkvetch poisoning. Primary cause of death, however, is from absorption of lethal amounts of 3-NPOH.

Miserotoxin is found primarily in green leaves, with smaller amounts in flowers, seeds, crowns, and roots. Plants are most poisonous from emergence to early pod (Williams and Binns, 1967). When leaves bleach after seed dispersal, miserotoxin content drops rapidly. Plants may contain $3.5 \%$ miserotoxin by dry weight during active growth, whereas bleached plants collected in August or September usually contain $0.4 \%$ or less. Bleached plants are those in which the top growth has died and no green color is present. Bleaching of leaves is of primary importance in detoxication. Miserotoxin concentration is unaffected when green leaves are dried in a forced air oven at $60 \mathrm{C}$. The potency of dried green plant remains high for 5 years or more (Williams and Binns, 1967).

Cronin and Williams (1964) reported that $2 \mathrm{lb}$./acre (ae) of the propylene glycol butyl ether esters of (2,4,5-trichlorophenoxy)acetic acid (2,4,5-T) and 2-(2,4,5-trichlorophenoxy)propionic acid (silvex) controlled timber milkvetch (var. $o b$ longifolius) on mountain meadows in Utah. Feeding trials with cattle established that plants treated with silvex and 2,4,5-T were less toxic than untreated ones (Williams and Binns, 1967). The superiority of silvex as a detoxicant appeared to be related to the rapidity with which it caused the leaves to bleach. Field observations indicated that high concentrations of miserotoxin were associated with green leaves and that any process that bleached the leaves, whether by herbicidal action or natural senescence, greatly reduced the concentration of the poison in the plant.

The purpose of the present experiment was to treat timber milkvetch with silvex and 2,4,5-T, to determine the rapidity of detoxication in treated against untreated plants, and to compare the two herbicides for effectiveness as detoxicants.

\section{Materials and Methods}

Plots were established in a randomized block on an open meadow at $6,500 \mathrm{ft}$ elevation in the Wasatch Mountains east of Iogan, Utah. Plots, replicated 4 times, measured 8 by $40 \mathrm{ft}$. Timber milkvetch (var. oblongifolius) occurred at a density of 1 to 2 plants per square foot. Plots were treated with the propylene glycol butyl ether esters of silvex and 2,4,5-T at $2 \mathrm{lb}$./acre (ae) on June 12, 1969, when plants were in full bloom. Whole plant samples (aerial portion) were collected weekly from each plot until treated and control plants were completely bleached. Samples were not collected during the week of June 26 because rain prevented travel to the area.

Foreign material was removed from samples and plant material was pooled by date and treatment.
The plants were dried at $60 \mathrm{C}$ in a forced air dryer, then ground to 40 mesh and stored in sealed containers. Percent miserotoxin was determined from the average of four samples from each date by the method previously described (Williams and Norris, 1969).

\section{Results and Discussion}

The concentration of miserotoxin in untreated plants increased for three weeks after treatment or until plants were in the early pod stage of growth (Table 1). Miserotoxin reached $2.5 \%$ on July 2 , then decreased slowly through July 24 . After July 31 the control plants bleached rapidly accompanied by a marked decrease in miserotoxin level at each date thereafter.

In the experiment, herbicidal action was retarded for nearly 2 weeks by rain which began 3 days after treatment. Treated plants bleached rapidly when normal weather returned in late June. The miserotoxin level in treated plants dropped below $2.0 \%$ within 1 week after treatment (June 19). This level was not reached in control plants until July 24. Miserotoxin content in treated plants was approximately one-third that of the controls four weeks after treatment. Silvex-treated plants contained the same level of miserotoxin July 2, three weeks after treatment, as did the controls on August 14, six weeks later. Both treated and untreated plants contained equivalent levels of miserotoxin when completely 
bleached; however, treated plants reached this stage 3 to 4 weeks earlier than the controls.

Although silvex-treated plants were generally lower in miserotoxin than 2,4,5-T-treated plants, the differences were too small for practical consideration. Silvex-treated plants usually bleach more quickly; therefore, silvex may provide more immediate detoxication than 2,4,5-T.

Once $50 \%$ or more of the leaves were no longer green, either from herbicide treatment or through natural senescence, miserotoxin content was usually less than $1 \%$. While livestock losses are unlikely after $50 \%$ of the leaves have bleached, no safe miserotoxin level should be assumed. Consideration must be given to the quality and density of other available forage and the class of livestock utilizing the infested area. Cattle are more susceptible to the poison than sheep.
Under range conditions, more lactating animals seem to die from ingestion of timber milkvetch than dry animals. Timber milkvetch treated with $2,4,5-\mathrm{T}$ and silvex should not be grazed until the plants are thoroughly bleached. The low miserotoxin content and the unpalatability associated with dried and bleached plants would then greatly reduce further danger of poisoning.

\section{Literature Cited}

Barneby, R. C. 1964. Atlas of North American Astragalus. Memoirs of the New York Bot. Garden Vol. 13. $1188 \mathrm{p}$.

Cronin, E. H., and M. C. Williams. 1964. Chemical control of timber milkvetch and effects on associated vegetation. Weeds 12:177-179.

MacDonald, M. A. 1952. Timber milk vetch poisoning on British Columbia ranges. J. Range Manage. 5:16-21.
Nicholson, H. H. 1963. The treatment of timber milk-vetch poisoning among cattle and sheep. Can. J. Anim. Sci. 43:237-240.

Stermitz, F. R., F. A. Norris, AND M. C. Williams. 1969. Miserotoxin, a new naturally occurring nitro compound. J. Am. Chem. Soc. 91:4599-4600.

Williams, M. C., and Wayne Binns. 1967. Toxicity of Astragalus miser Dougl., var. oblongifolius (Rydb.) Cronq. Weeds 15:359-362.

Williams, M. C., and F. A. Norkis. 1969. Distribution of miserotoxin in varieties of Astragalus miser Dougl. ex Hook. Weed Sci. 17:236-238.

Williams, M. C., F. A. Norris, and K. R. Van Kampen. 1970. Metabolism of misertoxin to 3-nitro-l-propanol in bovine and ovine ruminal fluids. Am. J. Vet. Res. 31:259-262. Williams, M. C., K. R. Van Kampen, ANd F. A. Norris. 1969. Timber milkvetch poisoning in chickens, rabbits, and cattle. Am. J. Vet. Res. $30: 2185-2190$. 